\title{
Research on Legal Issues and Legislative Countermeasures of Cross-border E-Commerce in China
}

\author{
TingTing $\mathrm{Yu}^{1, *}$ \\ ${ }^{1}$ School of Law, Ocean University of China, Qingdao, Shandong, China \\ ${ }^{*}$ Corresponding author. Email: 18150022085@ stu.ouc.edu.cn
}

\begin{abstract}
In recent years, China's leadership in the field of e-commerce has gradually increased, and import and export retail cross-border e-commerce platforms have been established one after another, driving the scale of China's import and export retail cross-border e-commerce transactions to continue to grow steadily. Based on the analysis of the current legal issues of China's cross-border retail e-commerce exports, this paper further investigates its legislative countermeasures and recommendations, aiming to promote in-depth research in this field, so that the results can better serve the benign development of China's cross-border e-commerce and contribute China's strength to the development of the world economy.
\end{abstract}

Keywords: Cross-border, e-commerce, legal issues, legislation, countermeasures

\section{INTRODUCTION}

Along with the development of FTZ, China's crossborder e-commerce has gradually entered a period of rapid development, with a huge expansion from transaction scale, transaction category to transaction amount. The development of cross-border e-commerce has brought tremendous changes both for the country, for enterprises and for consumers. For countries, it has broken down the barriers between countries and made international trade possible to become borderless trade. For enterprises, the development of cross-border ecommerce has broadened the path to international markets and multiplied the potential customer base. For consumers [1], the development of cross-border ecommerce gives them the opportunity to buy goods from other countries without having to leave home. Cross-border e-commerce is growing rapidly, but compared to traditional online shopping, it involves multiple countries and more complex intermediate links. As more consumers purchase goods from abroad through cross-border e-commerce, a series of problems such as substandard product quality, long delivery time and return service have emerged [2], which are reflected in the inadequate legal policies on cross-border ecommerce. This paper will be based on this further research.

\section{ANALYSIS OF THE CURRENT LEGAL SITUATION AND PROBLEMS OF CROSS- BORDER E-COMMERCE IN CHINA}

\subsection{Pre-trade}

\subsubsection{Government regulatory mechanism}

The current legal regulatory model is not well adapted to the demands of small and medium-sized enterprises, supporting laws and regulations and supervision and management system does not keep pace with the development of the times [3]. First, from the perspective of government services to enterprises, for example, in the customs clearance and release link, enterprises need to declare more items, procedures are also more complex, many of the declared content often cross overlap, but also can not achieve complete paperless customs clearance, customs clearance efficiency is low, the relevant laws and regulations do not make specific provisions in how to promote efficient customs clearance; Second, the regulatory standards of the cross-border market are not determined in the form of law down, for example, the coordination mechanism of customs, commodity inspection, industry and commerce, taxation and other departments is not yet sound, and a mechanism for information sharing and 
efficient supervision among competent governments has not yet been established, and there are inconsistencies in the documents of a normative nature formulated by various departments.

\subsubsection{Market access and platform regulation}

Market access and platform regulation is mainly the legislative regulation of the identity and credit recognition of the market subjects, platform access, platform rule-making, and management of trading subjects [4]. The Measures for the Administration of Network Transactions stipulate the information that natural persons should provide to the platform for transactions through network third-party platforms and the information that legal persons need to disclose on the home page of the network, and provide certain protection for the legitimate rights and interests of consumers [5]. The platforms mainly monitor the transactions in real time according to the rules they set and reasonably resolve the disputes according to the corresponding countermeasures introduced. However, at present, China has not introduced a set of specialized and strict laws and regulations for the management of cross-border platforms.

\subsubsection{Information Security Protection}

In terms of information security protection, China has not yet introduced a national law on data privacy protection, and the legislation for the protection of personal information on the Internet is mainly scattered in the "Electronic Signature Law", "Tort Liability Law", "Public Security Management Punishment Law" and other sectoral laws.

\subsection{Trading session}

\subsubsection{Payment and Settlement}

There are various payment methods for international trade, and with the development of cross-border ecommerce retail model, the use of third-party online payment platforms such as Paypel and Ali Secure Payment is becoming more and more common. Thirdparty payment refers to the use of non-bank third-party institutions to connect banks, sellers and consumers by using the credit guarantee and technical guarantee functions of payment platforms to realize monetary payment and flow, settlement and other functions for each subject. Cross-border third-party payment is a new industry that has emerged in response to the rapid development of the cross-border e-commerce retail industry, and the payer and receiver of its funds are generally not in the same country [6]. As an important support link for the development of cross-border ecommerce and a highly promising growth point for the financial industry, it has developed relatively rapidly in recent years, and there is a greater need to regulate its unreasonable phenomenon by legal means.

\subsubsection{Logistics and Circulation}

In general, the logistics mode of cross-border ecommerce retail export should be adapted to the characteristics of "small volume, multi-frequency and low amount" of parcels. At present, among the relevant documents issued in the field of logistics and circulation, "Opinions on Accelerating the Development of E-commerce in Circulation" puts forward the development goals of cross-border e-commerce logistics; "Opinions on Implementing Policies to Support Cross-border E-commerce Retail Exports" puts forward relevant solutions in the field of circulation such as customs, inspection and quarantine; "Announcement on Supervision of Goods and Articles Imported and Exported in Cross-border Trade The corresponding requirements are put forward for various aspects of import and export supervision of cross-border items, especially in the areas of enterprise registration and filing, cargo management, etc. In view of the analysis of the above prior regulatory documents, there are still many problems that need to be solved in the legal and regulatory aspects.

\subsubsection{Taxation}

At present, China mainly relies on the Customs Law, the Personal Income Tax Law, the Tax Collection and Administration Law and other laws to implement the taxation of cross-border e-commerce. The Announcement on Matters Relating to the Supervision of Inbound and Outbound Goods and Articles for Cross-border Trade in Electronic Commerce published by China Customs stipulates the conditions for the tax exemption procedures for enterprises' "goods list" and individuals' "articles list" [7]. The Notice on Adjustment of Management Measures for Inbound and Outbound Personal Postal Items stipulates the tax exemption standards for goods sent by individuals to different countries and regions, as well as the return of goods exceeding the limit for non-personal use or customs clearance procedures as required for goods. The Opinions on Implementing Policies Related to Supporting Cross-border E-commerce Retail Exports specifically proposes to develop a new taxation system for Chinese cross-border export enterprises and to develop policies on export tax rebates, value-added tax and tax exemption conditions for the subject by the taxation bureau, the Ministry of Finance and other relevant departments. The Notice on Taxation Policies for Cross-border E-Commerce Retail Exports proposes relevant taxation rules on the conditions for refund and exemption of consumption tax, VAT, etc. for exporters. However, on the whole, these laws tend to be broad and cannot yet effectively adapt to the development of the 
new economy, and China has not yet promulgated any tax laws specifically for cross-border e-commerce exports.

\subsection{Post-trade}

\subsubsection{Intellectual Property Disputes}

When conducting cross-border transactions, infringement of trademark rights, patent rights and copyrights are often encountered, leading to intellectual property disputes. China, as the original world's major manufacturing production and OEM country, had a lot of copycat products and repeatedly encountered intellectual property infringement problems [8]. The explosive development of cross-border e-commerce conforms to the development trend of the times, but is also related to its relatively low entry threshold, which has led to the uneven quality of many products on the platform and frequent incidents of counterfeiting or causing foreign intellectual property disputes. On the one hand, this reflects the lack of understanding of the concept of branding development of Chinese products and the IPR protection system in the target market when they go abroad. On the other hand, the imperfection of the law in the field of IPR may not be a deterrent for Chinese cross-border exporters and encourage their violations.

\subsubsection{After-sales disputes}

As disputes in cross-border e-commerce often arise between transaction subjects of two countries, and China currently lacks relevant independent laws to deal with cross-border electronic disputes, when disputes arise, they can generally only be resolved by invoking relevant legal provisions already in place in China. In terms of substantive law, the "Measures for the Administration of Internet Transactions" requires platforms to play a role in dispute resolution, and platforms should build their own dispute resolution and rights maintenance systems, participate in mediating disputes and support consumers to defend their legitimate rights and interests [9]. The Contract Law also contains relevant provisions involving dispute handling, of which Article 126(1) provides that parties to a foreign-related contract may choose for themselves the relevant law applicable to the resolution of the dispute. In terms of procedural law, the Law on the Application of Foreign-related Civil Relations Law provides that the parties in a foreign-related dispute may choose the law to be used by themselves, and also gives some explanations on the exceptions, in particular, the attribution of intellectual property rights in the dispute is also provided for [10]. In terms of after-sales disputes, although the overall law is relatively sound, there is a lack of after-sales protection system for consumers, and the law is unclear about the responsibility of the platform.

\section{RESEARCH ON LEGISLATIVE BASIS}

\subsection{Purpose of Legislation}

The purpose of the legislation is to effectively regulate the behavior and the steps of the whole process of the cross-border e-commerce retail export industry, to combat information leakage, infringement of intellectual property rights, tax evasion, counterfeiting and sale of fakes and other behaviors that harm the interests of all parties; to effectively mediate transaction disputes, avoid payment and other risks, to protect all participating parties to enjoy certain rights and actively fulfill the relevant obligations; to jointly maintain market fairness, protect the legitimacy of the relevant interests and claims, and take measures to promote trade facilitation, so that it will develop in a more standardized and rational direction; and to create a good environment for China's cross-border e-commerce retail export industry.

\subsection{Legislative Principles}

Legislation in the field of cross-border e-commerce retail export in China should uphold the principles of safeguarding national interests, fairness and impartiality, and focusing on efficiency. As the subjects of crossborder trade involve transactions across countries, national interests should be safeguarded without violating international rules, for example, international tax jurisdiction and territoriality should be adhered to in terms of tax laws. At the same time, each type of group should be treated fairly and impartially, for example, Class B and Class C sellers should be taxed together. In specific operations, attention should be paid to efficiency, for example, the coordination and unification of various departments and data sharing should be enhanced to improve customs clearance efficiency.

\section{LEGISLATIVE COUNTERMEASURES RESEARCH AND RECOMMENDATIONS}

In 2013, the EU Joint Research Center had pointed out in the Study Report on the Drivers and Impediments of Cross-border E-Commerce released that the absence of relevant laws and regulations would lead to the unavailability of cross-border e-commerce disputes, increase the difficulty of operation and hinder its development, so the relevant legislative work should be carried out in a timely manner. According to the practice of cross-border e-commerce in China and the problems that arise in its development, relevant laws, regulations, rules and treaties should be formulated in various aspects to implement the legislative work, and the relevant provisions of international organizations 
such as WTO should be effectively used to resolve disputes. As cross-border e-commerce retail export involves various aspects such as market access, payment, taxation and after-sales, each aspect has its own legal issues specificity, while each aspect also has universal common problems. Therefore, based on the compreh-ensive analysis of the above-mentioned parts, the following suggestions on the legislation of crossborder e-commerce retail export are proposed.

\subsection{Update legal terms}

First, a trial single law, revision of the original legal provisions or new judicial interpretation should be introduced. Due to the rapid development of crossborder e-commerce and its special characteristics, consideration can be given to the formulation of a single law to adapt to its development characteristics or through the timely revision of relevant laws, the introduction of new judicial interpretation to deal with the contradiction that the lagging nature of the law can not keep pace with the development of cross-border ecommerce. For example, all the contents related to cross-border e-commerce business (market access and withdrawal of cross-border enterprises, cross-border intellectual property protection, cross-border dispute resolution mechanism, product quality standard determination, cross-border payment and logistics, cross-border data messages and electronic contracts, etc.) can be incorporated into a new cross-border ecommerce law, so that there is a law to follow when problems arise in the field of cross-border e-commerce. Due to the rapid development of cross-border ecommerce, there is always a certain lag in the formulation of laws and regulations, which requires China to continuously amend and improve its legislation on cross-border e-commerce. For example, the legal effect of data messages is clarified in the Contract Law, computer crime-related crimes are added to the Criminal Law, and in the regulation of product quality in the field of cross-border e-commerce exports, the Product Quality Management Law can be amended to provide a legal basis for cross-border product quality disputes by adding and deleting relevant articles. Speeding up the formulation of a single law in the field of cross-border e-commerce and amending the existing regulations is the future development trend of China's cross-border ecommerce legislation.

\subsection{Participation in international rule-making}

Second, China should actively participate in the formulation of international rules for cross-border ecommerce, and should conform to the international legal framework when dealing with legal disputes. Since cross-border e-commerce involves cross-border trade with various countries around the world, the nature of trade is foreign-related, and international trade rules are bilateral or multilateral, so China needs to take international trade rules into consideration when formulating laws and regulations on cross-border ecommerce, try to conform to the adaptability of trade rules and international treaties, and conform to the laws and regulations under the relevant framework, and constantly strengthen regulatory exchanges and cooperation with various countries and regions. In addition, we should continue to strengthen regulatory exchanges and cooperation with countries and regions, actively participate in multilateral negotiations and international rules and treaties related to cross-border ecommerce, and discuss with countries to promote the development of global cross-border e-commerce international dispute resolution mechanism and the establishment of international regulatory models. At the same time, we should strengthen the interpretation of international law such as the WTO's Agreement on Trade in Services, improve China's legal system of cross-border trade in services, optimize the international interpretation of existing laws; and draw on the general rules of the United Nations Commission on International Trade Law on e-commerce legislation to develop a legal system suitable for China's cross-border e-commerce.

\subsection{Legislation defines rights and obligations}

Third, the rights and obligations of each subject should be clarified. Cross-border e-commerce retail export disputes involving all parties involved, so the first thing is to clarify the rights and obligations of the main body of the market. To inspection and quarantine obligations of the subjects, for example, consumers shall have the obligation not to buy goods prohibited from entering or leaving the country; third-party platform shall have the implementation of supervision of ecommerce enterprises and regular reasonable review of goods obligations; enterprises shall have the product information to the relevant departments for the record, when the product problems active recall obligations; fourth-party service providers, especially for sellers to provide customs clearance services such as customs inspection logistics company Should have the obligation to check whether the goods comply with the relevant provisions before sealing the package.

\subsection{In conjunction with general law legislation}

Fourthly, the principle legal provisions and general legal provisions should be used in conjunction with each other. This requires more principle clauses to be set in the process of e-commerce legislation to be used in conjunction with general clauses to regulate business activities. This is because the principle clauses do not stipulate the specific specification content, but ensure the correctness of the development direction of crossborder e-commerce in the process of its development, 
and can play a proper restraining and restricting role in its general development, so the combination of principle clauses and general specific clauses in the future legislation of cross-border e-commerce will be conducive to the legislative work in line with the speed of upgrading network technology and the trend.

\subsection{Strengthening Intergovernmental Coordination}

Fifth, in terms of market supervision, coordination among governments should be strengthened, an integrated platform for customs clearance should be established, data channels of customs, finance, taxation, commodity inspection and other departments should be opened, the boundaries of responsibilities of each regulatory department should be clarified, effective unified supervision should be carried out, and joint assistance in law enforcement should be provided. Build a cross-border e-commerce industrial park to realize centralized management and "batch shipment and regular declaration". In terms of trade facilitation measures, a single window can be established to promote the efficiency of customs clearance and implement an "electronic list" system for enterprises, which can be centralized with aggregated electronic customs declarations, VAT invoices and other matters such as foreign exchange clearance and tax refunds. The Hangzhou model can be used as a reference to establish a universal one-stop comprehensive customs clearance service platform to improve the efficiency of law enforcement, promote the efficiency of customs clearance and logistics speed of enterprises in customs clearance and inspection, improve the competitiveness of products, and provide convenience for all parties involved through various measures.

\section{CONCLUSION}

On the whole, China's cross-border e-commerce started late and developed fast, and the relevant laws and regulations have a certain lag. At present, the law is mainly based on single-line laws, and no special foreign-related laws and regulations have been introduced, and the legal basis is scattered in the relevant laws and regulations, and the legal level of legislation and rules is low, and many disputes are still in the legal vacuum. In the pre-transaction government regulatory mechanism, market access and platform supervision, information security protection, payment, logistics, taxation and post-transaction intellectual property disputes, after-sales disputes and other major aspects of cross-border e-commerce retail exports there are still many legislative shortcomings. This requires the relevant regulatory authorities to take a holistic approach to solve the common problems of legal deficiencies in each link, but also to make up for the legislative deficiencies in each link from a specific perspective, so that the disputes in each area can be based on the law and promote the healthy and orderly development of China's cross-border e-commerce retail exports.

\section{REFERENCES}

[1] Xu R. Legal protection of information security in cross-border e-commerce in China $[\mathrm{J}]$. China Business Journal, 2021(03): 21-24.

[2] Zhang G. Legal regulation dilemma and countermeasures of cross-border e-commerce retail import in China[J]. Foreign Economic and Trade Practice, 2020(12): 25-28.

[3] Yao Y. Research on the current situation and countermeasures of legal regulation of cross-border ecommerce [J]. Modern Business, 2020(26): 53-54.

[4] Wei R. Research on the construction of the legal protection mechanism of cross-border e-commerce intellectual property rights in the free trade zone $[\mathrm{J}]$. Legal Expo, 2020(23): 91-92.

[5] Lin Y, Zhang Y. Legal risks of intellectual property rights in cross-border e-commerce developpment and response[J]. Law and Economy, 2020(06): 7-9.

[6] Tang M. Analysis of the current situation of legal regulation of cross-border e-commerce in China and discussion of countermeasures [J]. China Market, 2020(03): 159-160.

[7] Gao F, Li Q, Li Y. Research and analysis on the legal policy of cross-border e-commerce[J]. Electronic commerce, 2017(11): 36-38.

[8] Tang X. Research on the current situation of legal regulation of cross-border e-commerce in China and countermeasures [J]. Journal of Wuyi University (Social Science Edition), 2017, 19(03): 65-68+94.

[9] Zheng A. An analysis on the statutory taxation of cross-border e-commerce [J]. Development Research, 2016(04): 72-76.

[10] Pei S, Zhai H. Legal risk prevention of crossborder e-commerce under export orientation[J]. Journal of Jilin Radio and Television University, 2016(03): 39-40.. 